\title{
Lifestyle Factors Associated with BMI in a Spanish Graduate Population: The SUN Study
}

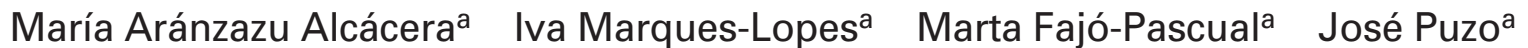 \\ Juan Blas Pérez ${ }^{\mathrm{a}}$ Maira Bes-Rastrollo ${ }^{\mathrm{b}, \mathrm{c}}$ Miguel Ángel Martínez-González \\ a Faculty of Health Sciences and Sports, University of Zaragoza, Huesca, \\ ${ }^{\mathrm{b}}$ Department of Preventive Medicine and Public Health, Clinica Universitaria-Medical School, University of Navarra, Pamplona, Spain \\ ${ }^{c}$ Department of Nutrition, Harvard School of Public Health, Boston, MS, USA
}

\section{Key Words}

Lifestyle factors · Body mass index · Education level . Alcohol consumption · Smoking habits · Marital status.

\section{Summary}

Objective: To study the association between BMI and lifestyle factors such as alcohol consumption, smoking habits, education level and marital status in a Spanish graduate population. Method: Cross-sectional analysis of 8,706 participants (3,643 men and 5,063 women) from the Seguimiento Universidad de Navarra (SUN) Study, an ongoing dynamic cohort study in Spain. Data on body weight, height and sociodemographic characteristics, and lifestyle habits were collected with self-administered validated questionnaires. Results: Among older participants (above sex-specific median age), educational level was a factor independently associated with BMI. University graduates with a lower educational level (3-year college degree or 5-year university degree) had a significantly higher BMI than those with doctorate which requires, at least, 8 years of university studies in Spain. Mean BMI was significantly higher among past smokers than among never smokers. Alcohol consumption, marital and smoking status were associated with BMI only among men. Conclusion: In a study whose members were all university graduates, several factors were independently associated with a higher BMI, such as less years of higher education, past smoking, marital status and higher alcohol consumption.

\section{Introduction}

The increasing worldwide prevalence of overweight and obesity is a major health problem strongly related to the risk of many chronic diseases [1,2].

BMI, a measure of weight adjusted for height, is a simple and inexpensive index that is often used as an indicator of overall adiposity. BMI is influenced by genes, diet and other aspects of lifestyle such as alcohol consumption, smoking habits, physical activity, and other sociodemographic factors such as educational level or marital status [3-7]. The association between smoking and a lower BMI has been documented in many studies [4, 8-10]. Besides, some investigations have shown that the nature of this relationship depends as well on educational level, gender, ethnicity, and frequency of smoking [4, 11-12]. Alcohol consumers usually add alcohol to their daily energy intake rather than substituting it for food, thus increasing positive energy balance [13]. However, epidemiological studies of alcohol consumption and BMI or body weight have provided contradictory results. In this context, cross-sectional data studies among men have shown positive [5, 14-16], negative [17] and non-significant associations $[13,18]$, whereas in women negative associations $[13,16,18]$ and non-significant associations [17] have been reported. Wannamethee et al. [19] reported a nonlinear relationship between alcohol and weight gain in a longitudinal study.

Some cross-sectional studies have shown that other important factors such as socioeconomic status were inversely associated with BMI [3, 6, 5, 20-23]. In most studies, educational level was used as an indicator of socioeconomic status and a strong inverse relationship between education and BMI has been observed mainly among women, especially within developed societies. Previous studies carried out in Spain showed that the distribution of overweight and obesity across socioeconomic status is similar to that reported for other geographical re-

\begin{tabular}{ll}
\hline KARGER & $\oplus$ 2008 S. Karger GmbH, Freiburg \\
Fax +49 7614520714 & Accessible online at: \\
$\begin{array}{l}\text { E-mail Information@Karger.de } \\
\text { www.karger.com }\end{array}$ & www.karger.com/ofa
\end{tabular}

Dr. Iva Marques Lopes

Facultad de Ciencias de la Salud y del Deporte

Universidad de Zaragoza

Plaza Universidad 3, 22002 - Huesca, Spain

Tel. +34 974 2393-91, Fax -92

E-mail imarques@unizar.es 
gions, with the percentage of obesity being higher among the elderly subjects of lower socioeconomic status and among the inhabitants of the North and North-Western regions of Spain $[24,25]$. However, there are scarce assessments of the effect of educational level on BMI within population subgroups who have already achieved a university degree. The assessment of lifestyle characteristics of highly educated segments of the population is interesting for public health purposes because population-wide lifestyle changes are usually preceded by changes affecting only university graduates.

To reverse the ongoing obesity epidemic, it is important to assess lifestyle determinants of BMI. The aim of this study was to evaluate the association between BMI and lifestyle factors such as alcohol consumption, smoking habits, marital status and educational level in a Spanish graduate population, using baseline data of the Seguimiento Universidad de Navarra (SUN) Study.

\section{Material and Methods}

\section{Study Population}

The SUN Study is a Spanish dynamic prospective cohort of university graduates designed to establish associations between diet and the occurrence of several diseases and chronic conditions including obesity [26]. It was designed in collaboration with the Harvard School of Public Health, and the methodologies are similar to those of large American cohorts such as the Nurses Health Study [27] or the Health Professionals Followup Study [28]. Details on the study design, recruitment strategy and follow-up methods are available elsewhere [26,29]. Briefly, beginning on December 1999, all Spanish alumni of the University of Navarra and several other professional collectives with a university degree received a letter of invitation to participate in the study, a questionnaire to respond and a postage-prepaid envelope to return the questionnaire [30]. This baseline questionnaire gathered information about sociodemographic variables, lifestyle factors, as well as information on health and diet through a validated semiquantitative food frequency questionnaire [29, 30]. Data from 12,490 participants recruited during the period 1999-2003 were included in the present analyses. Subjects who reported excessively high or low values for total energy intake (less than $800 \mathrm{kcal} / \mathrm{day}$ in men and $600 \mathrm{kcal} /$ day in women or more than $4,200 \mathrm{kcal} / \mathrm{day}$ in men and 3,500 kcal/day in women) were excluded because these extreme values are an indicator of low quality of the self-reported information.

On the other hand, subjects with missing values in variables of interest in the multivariate analysis, such as age, alcohol consumption, smoking status, marital status, educational level or leisure-time physical activity, were excluded, leaving a total of 8,706 participants $(3,643$ men and 5,063 women) available for the analyses. The University of Navarra Human Subjects Review Board approved the study protocol. Voluntary completion of the first self-administered questionnaire was considered to imply informed consent.

\section{Measures}

The questionnaire included different questions related to lifestyle, with 46 items for men and 54 items for women, including sociodemographic variables (sex, age, marital status and educational level), anthropometric data (weight, height), and health-related habits (alcohol consumption, smoking status and physical activity). BMI, the dependent variable, was calculated as the self-reported weight in kilograms divided by the square self-reported height in meters. The validity of self-reported weight was assessed in a subsample of the study. The mean relative error in self-reported weight was $1.45 \%$ ( $95 \%$ confidence interval $(95 \% \mathrm{CI})-2.03$ to -0.86$)$. The correlation coefficient (r) between measured and self-reported weight was 0.99 (95\% CI 0.98-0.99) [31].

The educational level was classified into four categories: doctorate, master's degree, 5-year university degree and 3-year college degree. According to smoking status, participants were classified as never smokers, past smokers, or current smokers. Marital status was categorized in three groups: single, married and widowed/separated/others.

Dietary habits were assessed using a semiquantitative food frequency questionnaire (136 items) that had been previously validated in Spain [32, 33]. The questionnaire included five items addressing the consumed amount of an assortment of alcoholic beverages (wine, beer and spirits). Nutrient scores were calculated as frequency by nutrient composition of a specified portion size, where frequencies were measured in nine categories ( $>6$ servings/day, 4-6 servings/day, 2-3 servings/day, 1 serving/day, 5-6 servings/week, 2-4 servings/week, 1 serving/week, 1-3 servings/month, and never or almost never) for each food item. Nutrient intake scores were computed using an ad hoc computer program specifically developed in SPSS language syntax for this purpose. A trained dietitian updated the nutrient data bank using the latest available information included in food composition tables for Spain $[34,35]$. Total alcohol was calculated as the sum of all types of alcohol consumed (wine, beer or spirits) and expressed in grams of alcohol per day.

Regarding alcohol consumption, subjects were categorized as: abstainer (0 $\mathrm{g} /$ day), light drinker ( 0.1 to $<5 \mathrm{~g} /$ day), moderate drinker (5-30 g/day for men and 5-20 g/day for women) and heavy drinker ( $>30 \mathrm{~g} /$ day for men and $>20 \mathrm{~g}$ /day for women).

\section{Statistical Analyses}

Dietary intakes were adjusted for total energy intake by using the residuals method [36].

The sample was split by gender, and each gender subgroup was further subdivided by the gender-specific median age. All analyses were carried out separately for the four sex by age subgroups.

Continuous variables were summarized by their mean and standard deviation (SD), whereas categorical variables were summarized using percentages. The frequencies of individuals in the different BMI categories (underweight, normal, overweight, and obesity) were calculated. Descriptive characteristics were compared using Pearson's chi square for categorical variables and ANOVA for continuous variables. The independent association of BMI with several lifestyle, demographic and socioeconomic variables such as alcohol consumption, smoking status, marital status and educational level was assessed using generalized linear models, including in the model the former covariates plus age, leisure-time physical activity (metabolic equivalent task-hours per week; MET-h/week) [37], total energy intake, energy-adjusted fiber intake, sugared-soft drinks consumption ( $\mathrm{ml} /$ day) and the consumption of fast food ( $\mathrm{g} /$ day) as continuous variables. We evaluated all first-order interactions (effect modification) through product terms.

To look for clusters of behaviors we calculated a score. Potential risk factors were categorized into quartiles. Protective ones (energy-adjusted fiber intake and leisure-time physical activity) were assigned 1-4 points from the first to the fourth quartiles, and risky ones (soft drinks and fast food) were assessed negatively, assigning 4-1 points from the first to the fourth quartile. Therefore, the total score ranged from 4 to 16 points. We categorized the score into 4 categories to adjust it in the multivariate model.

The average BMI and its $95 \% \mathrm{CI}$, predicted by the multivariate model for each of the variables in the model, was reported. Statistical significance was set at $\mathrm{p}<0.05$ when the mean BMI for each category was compared with respect to the mean BMI of the reference category.

Analyses were performed using SPSS version 11.0 (SPSS Inc, Chicago, IL, USA). 
Table 1. Descriptive ${ }^{a}$ characteristics in men, according to age groups (median cut-off) $^{\mathrm{b}}$

\begin{tabular}{|c|c|c|}
\hline & $\begin{array}{l}\text { Men }<39.2 \\
\text { years }^{c} \\
(n=1,822)\end{array}$ & $\begin{array}{l}\text { Men }>39.2 \\
\text { years }^{c} \\
(n=1,821)\end{array}$ \\
\hline Age, years ${ }^{\mathrm{d}}$ & $30.6 \pm 4.7$ & $50.8 \pm 7.2$ \\
\hline $\mathrm{BMI}, \mathrm{kg} / \mathrm{m}^{2 \mathrm{~d}}$ & $24.6 \pm 2.8$ & $26.0 \pm 3.0$ \\
\hline Physical activity, MET-h/week ${ }^{\mathrm{e}}$ & $32.0 \pm 29.3$ & $29.3 \pm 25.5$ \\
\hline Total energy intake, $\mathrm{kcal} /$ day $^{\mathrm{d}}$ & $2,621.2 \pm 681.4$ & $2,342.4 \pm 704.4$ \\
\hline Total fat intake, $\%$ of energy ${ }^{d}$ & $37.9 \pm 5.7$ & $35.2 \pm 6.6$ \\
\hline Protein intake, $\%$ of energy ${ }^{\mathrm{d}}$ & $17.4 \pm 2.9$ & $43.1 \pm 8.2$ \\
\hline Carbohydrate intake, $\%$ of energy & $42.3 \pm 6.8$ & $17.9 \pm 3.5$ \\
\hline Fiber intake, g/day ${ }^{\mathrm{d}}$ & $28.9 \pm 25.2$ & $27.3 \pm 10.3$ \\
\hline Fast food intake, g/day ${ }^{\mathrm{d}}$ & $22.1 \pm 8.5$ & $16.0 \pm 18.4$ \\
\hline Sugared-soft drinks, ml/day ${ }^{\mathrm{d}}$ & $87.1 \pm 127.3$ & $42.7 \pm 105.0$ \\
\hline \multicolumn{3}{|l|}{ Marital status, $\%$ d } \\
\hline Single & 62.6 & 13.1 \\
\hline Married & 36.0 & 82.5 \\
\hline Widowed/separated/others & 1.4 & 4.4 \\
\hline \multicolumn{3}{|l|}{ Alcohol consumption, $\%{ }^{d}$} \\
\hline $0 \mathrm{~g} /$ day (abstainer) & 10.6 & 11.0 \\
\hline 0.1 to $<5$ g/day (light drinker) & 34.3 & 29.0 \\
\hline 5-30 g/day (moderate drinker) & 51.5 & 51.2 \\
\hline$>30$ g/day (heavy drinker) & 3.6 & 8.8 \\
\hline \multicolumn{3}{|l|}{ Smoking status, $\%^{\mathrm{d}}$} \\
\hline Never & 58.7 & 32.3 \\
\hline Current & 25.2 & 20.2 \\
\hline Past & 16.0 & 47.5 \\
\hline \multicolumn{3}{|c|}{ Highest attained educational level, \% ${ }^{\mathrm{d}}$} \\
\hline Doctorate & 10.6 & 21.6 \\
\hline Master's degree & 11.5 & 5.0 \\
\hline 5-year university degree & 66.7 & 52.6 \\
\hline 3-year college degree & 11.2 & 20.9 \\
\hline
\end{tabular}

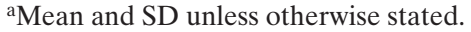

${ }^{\mathrm{b}} \mathrm{p}$ value from Pearson's chi square test for categorical variables and ANOVA test for continuous variables is reported.

'Sex-specific median age

$\mathrm{d}_{\mathrm{p}}<0.001$.

$\mathrm{e}_{\mathrm{p}}=0.003$.

\section{Results}

The descriptive characteristics of the study participants according to their gender and age group (above or below sexspecific median age) are shown in tables $1-3$. The age range for the whole sample was $18-78$ years. In men, the mean age was $40.7 \pm 11.8$ years and the median age 39.2 years, whereas in women the mean age was $34.2 \pm 9.7$ years and the median age was 31.5 years. Approximately half of men had moderate alcohol consumption. The majority of women had low alcohol consumption (light drinkers) or were non-drinkers (75.9 and $73.6 \%$ ). Only 3.6 and $8.8 \%$ of men and 1.3 and $3.9 \%$ of women were heavy drinkers. In both sex groups, participants below the median age were more likely to be physically active. However, these subjects reported higher intakes of fat, fast food and sugared-soft drinks than subjects with age above the median. The highest percentages of never smokers were
Table 2. Descriptive ${ }^{\mathrm{a}}$ characteristics in women, according to age groups (median cut-off) ${ }^{\mathrm{b}}$

\begin{tabular}{|c|c|c|}
\hline & $\begin{array}{l}\text { Women }<31.5 \\
\text { years }^{\mathrm{c}} \\
(\mathrm{n}=2,530)\end{array}$ & $\begin{array}{l}\text { Women }>31.5 \\
\text { years }^{c} \\
(n=2.533)\end{array}$ \\
\hline Age, years ${ }^{\mathrm{d}}$ & $26.4 \pm 2.7$ & $42.0 \pm 7.7$ \\
\hline $\mathrm{BMI}, \mathrm{kg} / \mathrm{m}^{2} \mathrm{~d}$ & $21.2 \pm 2.7$ & $22.6 \pm 3.0$ \\
\hline Physical activity, MET-h/week ${ }^{\mathrm{e}}$ & $25.3 \pm 23.0$ & $23.4 \pm 21.0$ \\
\hline Total energy intake, $\mathrm{kcal} / \mathrm{day}^{\mathrm{d}}$ & $2,327.7 \pm 572.5$ & $2,289.3 \pm 591.0$ \\
\hline Total fat intake, $\%$ of energy ${ }^{d}$ & $37.9 \pm 6.5$ & $37.5 \pm 7.0$ \\
\hline Protein intake, $\%$ of energy ${ }^{d}$ & $18.1 \pm 3.2$ & $18.3 \pm 3.6$ \\
\hline Carbohydrate intake, $\%$ of energy ${ }^{\mathrm{e}}$ & $42.8 \pm 7.2$ & $43.0 \pm 7.6$ \\
\hline Fiber intake, g/day ${ }^{\mathrm{d}}$ & $26.9 \pm 10.0$ & $29.0 \pm 10.3$ \\
\hline Fast food intake, g/day ${ }^{\mathrm{d}}$ & $23.1 \pm 17.7$ & $17.1 \pm 15.0$ \\
\hline Sugared-soft drinks, ml/day ${ }^{\mathrm{d}}$ & $79.5 \pm 118.1$ & $46.5 \pm 103.3$ \\
\hline \multicolumn{3}{|l|}{ Marital status, $\%$ d } \\
\hline Single & 80.9 & 25.0 \\
\hline Married & 18.5 & 69.3 \\
\hline Widowed/separated/others & 0.6 & 5.6 \\
\hline \multicolumn{3}{|l|}{ Alcohol consumption, $\%{ }^{\mathrm{d}}$} \\
\hline $0 \mathrm{~g} /$ day (abstainer) & 24.0 & 30.2 \\
\hline 0.1 to $<5 \mathrm{~g} /$ day (light drinker) & 51.9 & 43.4 \\
\hline 5-30 g/day (moderate drinker) & 22.8 & 22.6 \\
\hline$>30$ g/day (heavy drinker) & 1.3 & 3.9 \\
\hline \multicolumn{3}{|l|}{ Smoking status, $\% \mathrm{~d}$} \\
\hline Never & 55.3 & 43.0 \\
\hline Current & 30.1 & 23.2 \\
\hline Past & 14.7 & 33.8 \\
\hline \multicolumn{3}{|c|}{ Highest attained educational level, \% ${ }^{\mathrm{d}}$} \\
\hline Doctorate & 2.5 & 10.8 \\
\hline Master's degree & 7.6 & 6.1 \\
\hline 5-year university degree & 54.7 & 48.4 \\
\hline 3-year college degree & 35.2 & 34.7 \\
\hline
\end{tabular}

${ }^{a}$ Mean and SD unless otherwise stated.

b $\mathrm{p}$ value from Pearson's chi square test for categorical variables and ANOVA test for continuous variables is reported.

'Sex-specific median age

$\mathrm{d}_{\mathrm{p}}<0.001$.

${ }^{\mathrm{e}} \mathrm{p}=0.002$.

among subjects below the median age in both sex groups and among in women above the median age. Women were more likely to have a 3-year college degree than men. Among men, it was more frequent to be qualified with a doctorate or a 5 -year university degree or a master's degree. Table 3 shows that above the median age, $62.8 \%$ of men showed excess weight $(52.5 \%$ overweight and $10.3 \%$ obesity), whereas in women the percentage of excess weight was $17.6 \%(15.2 \%$ overweight and $2.4 \%$ obesity).

Tables 4, 5, 6 and 7 report adjusted associations of mean BMI with alcohol consumption, marital status, smoking status and educational level in men and women according to age group (above and below sex-specific median age). Age, total energy intake, leisure-time physical activity, energy-adjusted fiber intake, soft drinks and fast food consumption were also included in the model as potential confounders of the association between BMI and the former variables (alcohol consumption, 
Table 3. Distribution of BMI in men and women according to age groups (median cut-off)

\begin{tabular}{|c|c|c|c|c|c|c|c|c|}
\hline \multirow[t]{3}{*}{$\mathrm{BMI}^{\mathrm{a}}$} & \multicolumn{4}{|l|}{ Men } & \multicolumn{4}{|c|}{ Women } \\
\hline & \multicolumn{2}{|c|}{$<39.2$ years $^{\mathrm{b}}$} & \multicolumn{2}{|c|}{$>39.2$ years $^{\mathrm{b}}$} & \multicolumn{2}{|c|}{$<31.5$ years $^{\mathrm{b}}$} & \multicolumn{2}{|c|}{$>31.5$ years $^{\mathrm{b}}$} \\
\hline & $\mathrm{n}$ & $\%$ & $\mathrm{n}$ & $\%$ & $\mathrm{n}$ & $\%$ & $\mathrm{n}$ & $\%$ \\
\hline Underweight $\left(<18.5 \mathrm{~kg} / \mathrm{m}^{2}\right)$ & 6 & 0.3 & 4 & 0.2 & 241 & 9.5 & 111 & 4.4 \\
\hline Normal weight $\left(18.5-24.9 \mathrm{~kg} / \mathrm{m}^{2}\right)$ & 1,095 & 60.1 & 673 & 37.0 & 2,103 & 83.1 & 1,975 & 78.0 \\
\hline Overweight $\left(25-29.9 \mathrm{~kg} / \mathrm{m}^{2}\right)$ & 630 & 34.6 & 956 & 52.5 & 158 & 6.2 & 386 & 15.2 \\
\hline Obesity $\left(\geq 30 \mathrm{~kg} / \mathrm{m}^{2}\right)$ & 91 & 5.0 & 188 & 10.3 & 28 & 1.1 & 61 & 2.4 \\
\hline
\end{tabular}

${ }^{\mathrm{a}} \mathrm{p}<0.001$ from Pearson's chi square test.

${ }^{\mathrm{b} S e x}$-specific median age. marital status, smoking status and educational level). When clusters of behaviors were analyzed, no statistical differences were found with respect to the previous model.

Men who consumed the highest amount of alcohol ( $>30 \mathrm{~g} /$ day, i.e. heavy drinkers) had a significantly higher BMI than abstainers - a difference of 0.9 to $1.2 \mathrm{~kg} / \mathrm{m}^{2}$ (tables 4,5$)$. In men above the median age, a J-shaped relationship was found between alcohol consumption and BMI after adjustment for age, smoking status, marital status, educational level, total energy intake, leisure-time physical activity, energy-adjusted fiber intake, soft drinks, and fast food consumption. In women (tables $6,7)$, alcohol consumption was not associated with BMI. The effect of the type of alcoholic beverage consumed on BMI was also tested, but no significant results were detected (data not shown). Regarding marital status, married men below the median age had a significantly higher mean BMI $(25.4 ; 95 \%$ CI 25.1-25.7) than the reference group, i.e. single men $(24.6 ; 95 \%$ CI 24.3-24.9), after adjusting for age and the other abovementioned covariates. In women (tables 6,7 ) marital status was not associated with BMI.

Considering smoking habits, in all men age groups mean BMI was significantly higher among past smokers as compared with never smokers. In contrast, smoking habits were not associated with BMI in women. A significant inverse association was seen between BMI and higher educational level in both genders. All participants, except men below median age who had a 3-year college degree, had significantly higher BMI than participants who had a doctorate. In men, the adjusted differences were $1 \mathrm{~kg} / \mathrm{m}^{2}(\mathrm{p}<0.001)$, whereas in women these multivariate-adjusted differences were $0.8 \mathrm{~kg} / \mathrm{m}^{2}(\mathrm{p}<0.001)$ or $1 \mathrm{~kg} / \mathrm{m}^{2}$ $(\mathrm{p}=0.008)$. Among older participants (above sex-specific median age), those who exhibit a 5-year degree were associated with a higher BMI than those who exhibit a doctorate.

\section{Discussion}

Our study evaluated the effect of factors such as alcohol consumption, marital status, smoking status and educational level on BMI in the baseline assessment of a large cohort of Spanish university graduates.
Because other variables can confound the association between BMI and the formerly mentioned, covariates all analyses were further adjusted for age, leisure-time physical activity, total energy intake, energy-adjusted fiber intake, and the consumption of soft drinks and fast food.

Alcohol is known to reduce fat oxidation and to favor fat storage which may result in weight gain, because of an increase in BMI $[15,38,39]$. Several previous cross-sectional studies have investigated the relationship between alcohol consumption and BMI and have reported contradictory results. A prospective study among women showed that light alcohol consumers exhibited the lowest odds of weight gain, whereas higher levels of alcohol consumption were associated with increased weight gain, rendering a U-shaped dose-response trend [19]. In contrast with these findings we did not observe any relation between alcohol consumption and BMI in women.

In our investigation, only male heavy drinkers ( $>30 \mathrm{~g} /$ day) had higher BMI than abstainers. These findings corroborate previous studies that had also revealed a positive association between alcohol consumption and BMI in men exclusively [5, $15,16]$. Additionally, we observed in men above the median age (>39.2 years), a J-shaped relationship between total alcohol consumption and BMI. Lukasiewicz et al. [15] detected similar results in men. We did not detect a significant association in women, which may be due to the much higher number of abstainers and light drinkers among women in our study population.

In contrast, other authors found an inverse relationship between BMI and alcohol consumption [13, 40,41]. Additionally some cross-sectional studies suggest that men and women with low alcohol consumption tend to weigh less than non-drinkers or subjects with higher alcohol consumption [16].

These contradictory results from different studies may be explained by the type of alcoholic beverage consumed in the countries where these studies have been carried out. In a cross-sectional study [15] the relationship between BMI and wine consumption tended to show a J-shaped curve, whereas those between BMI and consumption of spirits showed a linear association for both sexes. In our study, the effect of alcoholic beverage preference was also tested. However, no significant differences were observed (data not shown). 
Table 4. Association of mean BMI with alcohol consumption, marital status, smoking status and educational level in men $<39.2$ years (below sex-specific median age)

\begin{tabular}{|c|c|c|c|c|}
\hline & \multirow{2}{*}{$\begin{array}{l}\text { Number } \\
\text { of sub- } \\
\text { jects }\end{array}$} & \multicolumn{2}{|c|}{ BMI, $\mathrm{kg} / \mathrm{m}^{2}$} & \multirow[t]{2}{*}{$\mathrm{p}$ value ${ }^{\mathrm{b}}$} \\
\hline & & mean $^{\mathrm{a}}$ & $95 \% \mathrm{CI}$ & \\
\hline \multicolumn{5}{|l|}{ Alcohol consumption } \\
\hline 0 g/day (abstainer) & 193 & 24.7 & $24.1,25.2$ & Ref. \\
\hline 0.1 to $<5 \mathrm{~g}$ /day (light drinker) & 625 & 24.6 & $24.2,25.1$ & 0.807 \\
\hline 5-30 g/day (moderate drinker) & 938 & 24.7 & $24.3,25.1$ & 0.965 \\
\hline$>30 \mathrm{~g} /$ day (heavy drinker) & 66 & 25.6 & $24.8,26.3$ & 0.027 \\
\hline \multicolumn{5}{|l|}{ Marital status } \\
\hline Single & 1,140 & 24.6 & $24.3,24.9$ & Ref. \\
\hline Married & 656 & 25.4 & $25.1,25.7$ & $<0.001$ \\
\hline Widowed/separated/other & 26 & 24.6 & $23.6,25.7$ & 0.834 \\
\hline \multicolumn{5}{|l|}{ Smoking status } \\
\hline Never & 1,070 & 24.7 & $24.3,25.2$ & Ref. \\
\hline Current & 460 & 24.7 & $24.2,25.2$ & 0.703 \\
\hline Past & 292 & 25.2 & $24.7,25.7$ & 0.011 \\
\hline \multicolumn{5}{|l|}{ Educational level } \\
\hline Doctorate & 194 & 24.7 & $24.1,25.3$ & Ref. \\
\hline Master's degree & 209 & 24.9 & $24.5,25.3$ & 0.807 \\
\hline 5-year university degree & 1,215 & 25.2 & $24.6,25.7$ & 0.444 \\
\hline 3-year college degree & 204 & 24.8 & $24.3,25.3$ & 0.132 \\
\hline
\end{tabular}

95\% CI $=95 \%$ confidence interval.

${ }^{a}$ Mean values for each factor were adjusted for the other factors presented in the table plus leisure-time physical activity, total energy intake, energyadjusted fiber intake, soft drinks and fast food.

bSignificance levels relative to the reference groups (Ref.) using generalized linear models.

The relationship between smoking habits and BMI could be mediated by the action of nicotine as an appetite suppressant or by the thermogenic effect of smoking [6]. This process may contribute to the increase in weight gain associated with smoking cessation [5]. Concerning smoking habits, we observed that only the group of ex-smokers in men had a higher BMI than the never smokers group. This inverse association between smoking and BMI in men is supported by previous studies $[5,10,11,39,42]$. Other authors observed ex-smokers to be heavier than non-smokers, but the association was present in both genders [16, 21, 43-45]. However, other studies have reported the association to be present only among women [6]. Finally, Seidell et al. [46] did not find any association in either sex. In our study, smoking habits were not associated with BMI in female participants. However some authors have suggested that social and psychological factors, such as the intention to be slim, might be a sufficient force to curb weight gain and to keep BMI at the level of never smokers after quitting $[10,47]$. Women might be particularly prone to this effect because of stronger social pressure supporting leanness among women.

Inconsistent results have been reported for the association between marital status and BMI, with higher prevalence of
Table 5. Association of mean BMI with alcohol consumption, marital status, smoking status and educational level in men (> 39.2 years (above sex-specific median age)

\begin{tabular}{|c|c|c|c|c|}
\hline & \multirow{2}{*}{$\begin{array}{l}\text { Number } \\
\text { of sub- } \\
\text { jects }\end{array}$} & \multicolumn{2}{|c|}{ BMI, $\mathrm{kg} / \mathrm{m}^{2}$} & \multirow[t]{2}{*}{$\mathrm{p}$ value } \\
\hline & & mean $^{\mathrm{a}}$ & $95 \% \mathrm{CI}$ & \\
\hline \multicolumn{5}{|l|}{ Alcohol consumption } \\
\hline $0 \mathrm{~g} /$ day (abstainer) & 200 & 25.3 & $24.8,25.7$ & Ref. \\
\hline 0.1 to $<5 \mathrm{~g} /$ day (light drinker) & 528 & 26.0 & $25.6,26.4$ & 0.001 \\
\hline 5-30 g/day (moderate drinker) & 933 & 26.0 & $25.6,26.1$ & 0.002 \\
\hline$>30 \mathrm{~g} /$ day (heavy drinker) & 160 & 26.5 & $26.0,27.0$ & $<0.001$ \\
\hline \multicolumn{5}{|l|}{ Marital status } \\
\hline Single & 238 & 25.7 & $25.3,26.2$ & Ref. \\
\hline Married & 1,503 & 26.0 & $25.8,26.3$ & 0.223 \\
\hline Widowed/separated/other & 80 & 26.0 & $25.4,26.7$ & 0.537 \\
\hline \multicolumn{5}{|l|}{ Smoking status } \\
\hline Never & 588 & 25.7 & $25.4,26.1$ & Ref. \\
\hline Current & 368 & 25.9 & $25.6,26.3$ & 0.343 \\
\hline Past & 865 & 26.1 & $25.8,26.5$ & 0.019 \\
\hline \multicolumn{5}{|l|}{ Educational level } \\
\hline Doctorate & 393 & 25.4 & $25.0,25.7$ & Ref. \\
\hline Master's degree & 91 & 25.8 & $25.5,26.0$ & 0.142 \\
\hline 5-year university degree & 957 & 25.9 & $25.6,26.1$ & 0.050 \\
\hline 3-year college degree & 380 & 26.4 & $26.0,26.8$ & $<0.001$ \\
\hline
\end{tabular}

$95 \% \mathrm{CI}=95 \%$ confidence interval.

${ }^{\mathrm{a}}$ Mean values for each factor were adjusted for the other factors presented in the table plus leisure-time physical activity, total energy intake, energyadjusted fiber intake, soft drinks and fast food.

bSignificance levels relative to the reference groups (Ref.) using generalized linear models.

obese subjects in both married and unmarried subjects [48]. In a representative cross-sectional study of 15 European countries, Martínez et al. [21] found that single individuals were less prone to become obese than couples or widowed/divorced people. Our findings are consistent with the previous study in that BMI of married men below median age ( $<39.2$ years) was significantly higher than BMI of single men. Studies carried out in other countries also showed that married people tend to have a higher BMI and that entering marriage influences physical characteristics such as body weight [49-51]. One of the main reasons for this is that married life may bring regular meal patterns and an increase in the amount of food ingested because of more frequent social interactions.

The small number of widowed/separated/others, particularly among male members of our study, may have contributed to insufficient statistical power to detect significance. In other studies, marital status was not significantly associated with BMI [42, 43, 48]. Tavani et al. [40] reported that BMI in women was directly associated with marriage. However, we did not found any association between BMI and marital status among women.

In our investigation, the level of university studies in both men and women was related to BMI. Indeed, we observed a statis- 
Table 6. Association of mean BMI with alcohol consumption, marital status, smoking status and educational level in women $<31.5$ years (below sex-specific median age)

\begin{tabular}{|c|c|c|c|c|}
\hline & \multirow{2}{*}{$\begin{array}{l}\text { Number } \\
\text { of sub- } \\
\text { jects }\end{array}$} & \multicolumn{2}{|c|}{ BMI, $\mathrm{kg} / \mathrm{m}^{2}$} & \multirow[t]{2}{*}{$\mathrm{p}$ value } \\
\hline & & mean $^{\mathrm{a}}$ & $95 \% \mathrm{CI}$ & \\
\hline \multicolumn{5}{|l|}{ Alcohol consumption } \\
\hline 0 g/day (abstainer) & 607 & 21.9 & $21.4,22.5$ & Ref. \\
\hline 0.1 to $<5 \mathrm{~g}$ /day (light drinker) & 1,314 & 21.7 & $21.3,22.3$ & 0.805 \\
\hline 5-30 g/day (moderate drinker) & 577 & 21.7 & $21.1,22.2$ & 0.765 \\
\hline$>30 \mathrm{~g} /$ day (heavy drinker) & 32 & 22.3 & $21.2,23.3$ & 0.451 \\
\hline \multicolumn{5}{|l|}{ Marital status } \\
\hline Single & 2,047 & 21.2 & $21.0,21.5$ & Ref. \\
\hline Married & 468 & 21.2 & $20.8,21.6$ & 0.421 \\
\hline Widowed/separated/other & 15 & 23.4 & $21.9,24.7$ & 0.303 \\
\hline \multicolumn{5}{|l|}{ Smoking status } \\
\hline Never & 1,398 & 21.7 & $21.2,22.3$ & Ref. \\
\hline Current & 761 & 21.9 & $21.4,22.5$ & 0.907 \\
\hline Past & 371 & 22.0 & $21.5,22.7$ & 0.487 \\
\hline \multicolumn{5}{|l|}{ Educational level } \\
\hline Doctorate & 62 & 21.3 & $20.5,22.1$ & Ref. \\
\hline Master's degree & 193 & 22.0 & $21.4,22.7$ & 0.094 \\
\hline 5-year university degree & 1,385 & 22.0 & $21.5,22.6$ & 0.042 \\
\hline 3-year college degree & 890 & 22.3 & $21.8,22.8$ & 0,008 \\
\hline
\end{tabular}

$95 \% \mathrm{CI}=95 \%$ confidence interval.

${ }^{a}$ Mean values for each factor were adjusted for the other factors presented in the table plus leisure-time physical activity, total energy intake, energyadjusted fiber intake, soft drinks and fast food.

bSignificance levels relative to the reference groups (Ref.) using generalized linear models.

tically significant inverse association between educational level and BMI. Our findings are in agreement with previous studies $[3,5,6,21,23,40,42,43,46,48,52]$. The influence of educational level in the prevalence of obesity in Spanish adult population had been previously assessed in the SEEDO's study [23]. The authors reported an inverse relationship between the level of education and the prevalence of obesity in both genders. Similar results have been found in other studies conducted in Spain $[53,54]$. In our study, overweight and obesity in women were much less frequent in female participants as compared with Spanish population (32\% overweight and $16 \%$ obesity) [55]. This fact may be due to the specific population studied which is constituted by young women with a university degree.

Summarizing the findings of our study, alcohol consumption, marital status and smoking habits were factors associated with BMI in men only, whereas educational level was associated with BMI in both genders. The novel finding of our study is that we observed an inverse association between university education level and BMI. This may reveal that even within segments of the population where all subjects have already attained a university degree, the BMI differences between different degrees attained could be an indicator of different so-
Table 7. Association of mean BMI with alcohol consumption, marital status, smoking status and educational level in women $>31.5$ years (above sex-specific median age)

\begin{tabular}{|c|c|c|c|c|}
\hline & \multirow{2}{*}{$\begin{array}{l}\text { Number } \\
\text { of sub- } \\
\text { jects }\end{array}$} & \multicolumn{2}{|c|}{ BMI, $\mathrm{kg} / \mathrm{m}^{2}$} & \multirow[t]{2}{*}{$\mathrm{p}$ value } \\
\hline & & mean $^{\mathrm{a}}$ & $95 \% \mathrm{CI}$ & \\
\hline \multicolumn{5}{|l|}{ Alcohol consumption } \\
\hline $0 \mathrm{~g} /$ day (abstainer) & 764 & 22.5 & $22.2,22.8$ & Ref. \\
\hline 0.1 to $<5 \mathrm{~g} /$ day (light drinker) & 1,099 & 22.3 & $22.0,22.5$ & 0.140 \\
\hline 5-30 g/day (moderate drinker) & 572 & 22.3 & $22.0,22.6$ & 0.796 \\
\hline$>30 \mathrm{~g} /$ day (heavy drinker) & 98 & 22.4 & $21.8,23.0$ & 0.779 \\
\hline \multicolumn{5}{|l|}{ Marital status } \\
\hline Single & 634 & 22.6 & $22.3,22.8$ & Ref. \\
\hline Married & 1,756 & 22.4 & $22.1,22.6$ & 0.949 \\
\hline Widowed/separated/other & 143 & 22.2 & $21.7,22.7$ & 0.112 \\
\hline \multicolumn{5}{|l|}{ Smoking status } \\
\hline Never & 1,089 & 22.4 & $22.1,22.7$ & Ref. \\
\hline Current & 588 & 22.1 & $21.8,22.4$ & 0.750 \\
\hline Past & 856 & 22.6 & $22.3,22.9$ & 0.230 \\
\hline \multicolumn{5}{|l|}{ Educational level } \\
\hline Doctorate & 274 & 22.0 & $21.6,22.4$ & Ref. \\
\hline Master's degree & 155 & 22.2 & $22.2,22.7$ & 0.532 \\
\hline 5-year university degree & 1,226 & 22.4 & $22.5,23.1$ & 0.030 \\
\hline 3 -year college degree & 878 & 22.8 & $21.7,22.7$ & $<0.001$ \\
\hline
\end{tabular}

$95 \% \mathrm{CI}=95 \%$ confidence interval.

${ }^{a}$ Mean values for each factor were adjusted for the other factors presented in the table plus leisure-time physical activity, total energy intake, energyadjusted fiber intake, soft drinks and fast food.

bSignificance levels relative to the reference groups (Ref.) using generalized linear models.

cioeconomic status in this specific population. Some authors had reported that in both men and women, employment status (a measure of socioeconomic status) was related to BMI [58]. In this way, if different university education levels in our investigation (for example a 3-year college degree vs. doctorate) reflect different employment statuses, they might be an indicator of participants' socioeconomic status.

A limitation of the present investigation is its reliance on selfreports. A tendency for participants to underestimate their weight and overestimate their height and to describe their lifestyles healthier than they actually are (social desirability bias) may have affected our results. However, the validity of self-reports of the participants in this study regarding several key variables, including body weight and BMI, has been sufficiently shown in previous investigations [29, 31, 37]. Another possible shortcoming is that waist circumference was not measured, although BMI is an universally accepted measuring tool to determine body fatness.

Another limitation is the cross-sectional design of the study, which does not provide evidence for the causal nature of the association between the studied factors and BMI. On the other hand, considering the fact that there are other possible important confounders such as the different components of 
the diet, we adjusted for dietary variables (i.e. total energy intake, energy-adjusted fiber intake, soft drinks and fast food consumption) which have been found associated with BMI or weight in the SUN study $[29,56,57]$. Additionally, unbalanced size groups (i.e. comparing. educational level or marital status categories), tend to produce wider confidence intervals which might have reduced the ability of our study to detect significant differences among certain groups.

In conclusion, this study suggests that educational level is a factor independently associated with BMI in both genders, whereas alcohol consumption, marital status and smoking status were associated with BMI only in men.

In our investigation these factors seem to increase the risk of obesity , but these findings need to be confirmed using longitudinal data. Public health programmers should consider these factors when planning strategies aimed at preventing or reducing the problem of obesity. Our findings may help in designing intervention measures for prevention and/or management of obesity.

\section{Acknowledgements}

We are indebted to the participants of the SUN Study for their continued cooperation and participation. We also would like to thank other members of the SUN Study group including J.A. Martínez, J. de Irala, C. de la Fuente, M. Seguí-Gómez, M. Serrano-Martínez, A. Tortosa and Z. Vázquez from the University of Navarra, F. Guillen-Grima from the Public University of Navarra, M. Delgado-Rodriguez from the University of Jaen, J. Llorca from the University of Cantabria, and A. Sánchez-Villegas from the University of Las Palmas.

Sponsorship: Instituto Estudios Altoaragoneses (PI41/2005), Navarre Regional Government (PI41/2005) and the Spanish Ministry of Health (Instituto de Salud Carlos III, Fondo de Investigaciones Sanitarias, projects PI040233, PI042241, PI050514, PI050976, and RD 06/0045).

Author contribution: M-G MA and B-R M were responsible for study design, obtaining funding and data analysis. M-L I, MA A and M F-P, were responsible for data collection and analysis and obtaining funding, MA A and M-L I were responsible for data analysis and drafting the manuscript, P-F J and P JB were responsible for literature search and additional data analyses.

All authors have reviewed critically and approved the manuscript. None of the authors had any conflict of interest from a financial, personal, or professional aspect in relation to the findings of this study.

\section{References}

1 World Health Organization (WHO): Obesity: preventing and managing the global epidemic. Report of a WHO consultation on obesity, Geneva, 3-5 June, 1997. Geneva, WHO, 1998.

2 WHO/FAO: Diet, nutrition and the prevention of chronic diseases. World Health Organ Tech Rep Ser 2003;916:i-viii, 1-149,.

3 Molarius A, Seidell JC, Sans S, Tuomilehto J, Kuulasmaa K: Educational level, relative body weight, and changes in their association over 10 years: an international perspective from the WHO MONICA Project. Am J Public Health 2000;90:12601268.

4 Pednekar MS, Gupta PC, Shukla HC, Hebert JR Association between tobacco use and body mass index in urban Indian population: implications for public health in India. BMC Public Health 2006;6: 70.

5 Duvigneaud N, Wijndaele $\mathrm{K}$, Matton L, Deriemaeker P, Philippaerts R, Lefevre J, Thomis M, Duquet W: Socio-economic and lifestyle factors associated with overweight in Flemish adult men and women. BMC Public Health 2007;26:7-23.

6 Tzotzas T, Konstantinidis T, Bougoulia M, Krassas GE: Factors associated with body mass index in adults from Northern Greece. Hormones 2004;3: 111-119.

7 Elliott RM, Johnson IT: Nutrigenomic approaches for obesity research. Obes Rev 2007:8:77-81.

8 Molarius A, Seidell JC, Kuulasmaa K, Dobson AJ, Sans S: Smoking and relative body weight: an international perspective from the WHO MONICA Project. J Epidemiol Community Health 1997;51: 252-260.

9 Bovet P, Ross AG, Gervasoni JP, Mkamba M, Mtasiwa DM, Lengeler C, Whiting D, Paccaud F Distribution of blood pressure, body mass index and smoking habits in the urban population of Dar es Salaam, Tanzania, and associations with socioeconomic status. Int J Epidemiol 2002;31:240-247.
10 John U, Hanke M, Rumpf HJ, Thyrian JR: Smoking status, cigarettes per day, and their relationship to overweight and obesity among former and current smokers in a national adult general population sample. Int J Obes 2005;29:1289-1294.

11 Molarius A, Seidell JC: Differences in the association between smoking and relative body weight by level of education. Int J Obes Relat Metab Disord 1997;21:189-196.

12 Laaksonen M, Rahkonen O, Prattala R: Smoking status and relative weight by educational level in Finland, 1978-1995. Prev Med 1998:27:431-437.

13 Wannamethee SG, Shaper AG: Alcohol, body weight, and weight gain in middle-aged men. Am J Clin Nutr 2003;77:1312-1317.

14 Rosmond R, Lapidus L, Bjorntorp P: The influence of occupational and social factors on obesity and body fat distribution in middle-aged men. Int $\mathrm{J}$ Obes Relat Metab Disord 1996:20:599-607.

15 Lukasiewicz E, Mennen LI, Bertrais S, Arnault N, Preziosi P, Galan P, Hercberg S: Alcohol intake in relation to body mass index and waist-to-hip ratio: the importance of type of alcoholic beverage. Public Health Nutr 2005;8:315-320.

16 Lahti-Koski M, Pietinen P, Heliovaara M, Vartiainen E: Associations of body mass index and obesity with physical activity, food choices, alcohol intake, and smoking in the 1982-1997 FINRISK Studies. Am J Clin Nutr 2002;75:809-817.

17 Gruchow HW, Sobocinski KA, Barboriak JJ, Scheller JG: Alcohol consumption, nutrient intake and relative body weight among US adults. Am J Clin Nutr 1985;42:289-295.

18 Sherwood NE, Jeffery RW, French SA, Hannan PJ, Murray DM: Predictors of weight gain in the Pound of Prevention study. Int J Obes Relat Metab Disord 2000;24:395-403.

19 Wannamethee SG, Field AE, Colditz GA, Rimm EB: Alcohol intake and 8-year weight gain in women: a prospective study. Obes Res 2004;12: 1386-1396.
20 Martikainen PT, Marmot MG: Socioeconomic differences in weight gain and determinants and consequences of coronary risk factors. Am J Clin Nutr 1999;69:719-726.

21 Martinez JA, Kearney JM, Kafatos A, Paquet S, Martinez-Gonzalez MA: Variables independently associated with self-reported obesity in the European Union. Public Health Nutr 1999;2:125-133.

22 Huot I, Paradis G, Ledoux M; Quebec Heart Health Demonstration Project research group: Factors associated with overweight and obesity in Quebec adults. Int J Obes Relat Metab Disord 2004; 28:766-774.

23 Wilsgaard T, Jacobsen BK, Arnesen E: Determining lifestyle correlates of body mass index using multilevel analyses: the Tromso Study, 1979-2001. Am J Epidemiol 2005;162:1179-1188.

24 Aranceta J, Perez-Rodrigo C, Serra-Majem L, Ribas L, Quiles-Izquierdo J, Vioque J, Foz M, and Spanish Collaborative Group for the Study of Obesity: Influence of sociodemographic factors in the prevalence of obesity in Spain. The SEEDO'97 Study. Eur J Clin Nutr 2001;55:430-435.

25 Varo JJ, Martínez-González MA, Martínez JA: Obesity prevalence in Europe. An Sist Sanit Navar 2002;25:103-108.

26 Martínez-González MA, Sánchez-Villegas A, De Irala J, Marti A, Martínez JA: Mediterranean diet and stroke: objectives and design of the SUN Project. Nutr Neurosci 2002;5:65-73.

27 Liu S, Manson JE, Stampfer MJ, Rexrode KM, Hu FB, Rimm EB, Willet WC: Whole grain consumption and risk of ischemic stroke in women. JAMA 2000;284:1534-1540.

$28 \mathrm{Hu}$ FB, Rimm EB, Stampfer MJ, Ascherio A, Spiegelman D, Willet WC: Prospective study of major dietary patterns and risk of coronary heart disease in men. Am J Clin Nutr 2000;71:912-921.

29 Segui-Gomez M, de la Fuente C, Vazquez Z, de Irala J, Martinez-Gonzalez MA: Cohort profile: The 'Seguimiento Universidad de Navarra' (SUN) study. Int J Epidemiol 2006;35:1417-1422. 
30 Martinez-Gonzalez MA: The SUN cohort study. Public Health Nutr 2006:9:127-131.

31 Bes-Rastrollo M, Pérez Valdivieso JR, Sánchez-Villegas A, Alonso A, Martínez-González MA: Validación del peso e índice de masa corporal auto-declarados de los participantes de una cohorte de graduados universitarios. Rev Esp Obes 2005;3: 183-189.

32 Martín-Moreno JM, Boyle P, Gorgojo L, Maisonneuve P, Fernandez-Rodriguez JC, Salvini S, Willet WC: Development and validation of a food frequency questionnaire in Spain. Int J Epidemiol 1993;22:512-519.

33 Willet WC, Sampson L, Stampfer MJ, Rosner B, Bain C, Witschi J: Reproducibility and validity of a semiquantitative food frequency questionnaire. Am J Epidemiol 1985;122:51-65.

34 Mataix J: Tabla de composición de alimentos [Food composition tables], 4th ed. Granada, Universidad de Granada, 2003 (in Spanish).

35 Moreiras O: Tablas de composición de alimentos [Food compositiontables], 7th ed. Madrid, Ediciones Pirámide, 2003 (in Spanish).

36 Willett WC, Stampfer M: Implications of total energy intake for epidemiologic analyses; in Willett WC (ed): Nutritional Epidemiology, 2nd ed. New York, Oxford University Press, 1998, pp 273-301.

37 Martínez-González MA, López-Fontana C, Varo JJ, Sánchez-Villegas A, Martinez JA: Validation of the Spanish version of the physical activity questionnaire used in the Nurses' Health Study and the Health Professionals' Follow-up Study. Public Health Nutr 2005;8:920-927.

38 Prentice AM: Alcohol and obesity. Int J Obes Relat Metab Disord 1995;19(suppl 5):S44-S50.

39 Arif AA, Rohrer JE: Patterns of alcohol drinking and its association with obesity: data from the Third National Health and Nutrition Examination Survey. BMC Public Health 2005;5:126

40 Tavani A, Negri E, La Vecchia C: Determinants of body mass index: a study from northern Italy. Int J Obes Relat Metab Disord 1994;18:497-502.
41 Männistö S, Uusitalo K, Roos E, Fogelholm M, Pietinen P: Alcohol beverage drinking, diet and body mass index in a cross-sectional survey. Eur J Clin Nutr 1997;51:326-332.

42 Scali J, Siari S, Grosclaude P, Gerber M: Dietary and socio-economic factors associated with overweight and obesity in a southern French population. Public Health Nutr 2004;7:513-522.

43 Ostbye T, Pomerleau J, Speechley M, Pederson LL, Speechley KN: Correlates of body mass index in the 1990 Ontario Health Survey. CMAJ 1995;152: 1811-1817.

44 Flegal KM, Troiano RP, Pamuk ER, Kuczmarski RJ, Campbell SM: The influence of smoking cessation on the prevalence of overweight in the United States. N Engl J Med 1995;333:1165-1170.

45 Sundquist J, Johansson SE: The influence of socioeconomic status, ethnicity and lifestyle on body mass index in a longitudinal study. Int J Epidemiol 1998; 27:57-63.

46 Seidell JC, Cigolini M, Deslypere JP, Charzewska J, Ellsinger BM, Cruz A: Body fat distribution in relation to physical activity and smoking habits in 38year-old European men. The European Fat Distribution Study. Am J Epidemiol 1991;133:257-265.

47 Bamia C, Trichopoulou A, Lenas D, Trichopoulos D: Tobacco smoking in relation to body fat mass and distribution in a general population sample. Int J Obes Relat Metab Disord 2004;28:1091-1096.

48 van Lenthe FJ, Droomers M, Schrijvers CT, Mackenbach JP: Socio-demographic variables and 6 year change in body mass index: longitudinal results from the GLOBE study. Int J Obes Relat Metab Disord 2000;24:1077-1084.

49 Sobal J, Rauschenbach BS, Frongillo EA Jr: Marital status, fatness and obesity. Soc Sci Med 1992;35: 915-923.

50 Sobal J, Rauschenbach B, Frongillo EA: Marital status changes and body weight changes: a US longitudinal analysis. Soc Sci Med 2003;56:1543-1555.
51 Lee S, Cho E, Grodstein F, Kawachi I, Hu FB, Colditz GA: Effects of marital transitions on changes in dietary and other health behaviours in US women. Int J Epidemiol 2005;34:69-78.

52 Wandell PE, Ponzer S, Johansson SE, Sundquist K Sundquist J: Country of birth and body mass index: a national study of 2,000 immigrants in Sweden. Eur J Epidemiol 2004;19:1005-1010.

53 Gutierrez-Fisac JL, Regidor E, Rodriguez C: Trends in obesity differences by educational level in Spain. J Clin Epidemiol 1996;49:351-354.

54 Gutierrez-Fisac JL, Regidor E, Banegas Banegas JR, Rodriguez Artalejo F: The size of obesity differences associated with educational level in Spain, 1987and 1995/97. J Epidemiol Community Health 2002;56:457-460.

55 Aranceta J, Pérez Rodrigo C, Serra Majem L, Ribas Barba L, Quiles Izquierdo J, Vioque J, Tur Marí J, Mataix Verdú J, Llopis González J, Tojo R, Foz Sala M, for the Grupo Colaborativo para el Estudio de la Obesidad en Espana: Prevalence of obesity in Spain: results of the SEEDO 2000 study. Med Clin (Barc) 2003;120:608-612.

56 Bes-Rastrollo M, Martínez-González MA, Sánchez-Villegas A, de la Fuente Arrillaga C, Martínez JA: Association of fiber intake and fruit/vegetable consumption with weight gain in a Mediterranean population. Nutrition 2006;22:504-511.

57 Bes-Rastrollo M, Sánchez-Villegas A, Gómez-Gracia E, Martínez JA, Pajares RM, Martínez-González MA: Predictors of weight gain in a Mediterranean cohort: the Seguimiento Universidad de Navarra Study. Am J Clin Nutr 2006;83:362-370.

58 Martikainen PT, Marmot MG: Socioeconomic differences in weight gain and determinants and consequences of coronary risk factors. Am J Clin Nutr 1999;69:719-726. 